\title{
PUSAT MODIFIKASI MOBIL DI PANTAI INDAH KAPUK
}

\author{
Andrew ${ }^{1)}$, Martin Halim ${ }^{2)}$ \\ 1) Program Studi S1 Arsitektur, Fakultas Teknik, Universitas Tarumanagara, affendy.andrew@gmail.com \\ 2) Program Studi S1 Arsitektur, Fakultas Teknik, Universitas Tarumanagara, martinhalim90@gmail.com
}

\begin{abstract}
Abstrak
Generasi millennial merupakan generasi yang lahir pada tahun 1981 hingga 2000. Generasi ini sangat dekat dengan berbagai macam perkembangan teknologi. Salah satu bidang teknologi yang digemari oleh generasi millenial yaitu teknologi otomotif. Hal ini ditandai dengan semakin meningkatnya rutinitas dari kegiatan mengenai otomotif yang diadakan dari tahun ke tahun seperti seminar, pameran, modifikasi, pengulasan, dll. Kegiatan yang paling disukai pada teknologi otomotif yaitu kegiatan modifikasi. Kegiatan modifikasi merupakan kegiatan yang dapat mengeksplorasi kreativitas kaun millennial yang dituangkan melalui teknologi otomotif. Kegiatan modifikasi otomotif dijadikan sebagai gaya hidup dan ilmu pengetahuan ringan yang baru. Sayangnya, Ibu Kota saat ini belum dapat memberikan ruang dan fasilitas yang memadahi terhadap kegiatan modifikasi otomotif tersebut. Semua kegiatan modifikasi ini masih dilakukan secara konvensional dan di tempat-tempat terbuka. Sedangkan jika dilihat kembali, kegiatan modifikasi otomotif dengan fasilitas dan ruang yang memadai akan meningkatkan tingkat kreativitas kaum millennial sehingga hasilnya dapat bersaing dengan negara luar. Dengan menelusuri berbagai pengamatan di era millennial ini, segala bentuk informasi mengenai otomotif sangat mudah dikemas dengan media sosial seperti youtube, instagram, twitter, dll. Untuk itu penulis mengkaji bagaimana arsitektur menciptakan sebuah wadah yang berfungsi secara maksimal untuk kegiatan modifikasi otomotif dengan sebuah proyek arsitektur yang disebut dengan Pusat Modifikasi Mobil di Pantai Indah Kapuk. Metode yang dilakukan adalah metode studi literatur dengan mengkaji tipologi ruang dari beberapa proyek yang sudah terbangun. Sebagai respon dari kebiasaan kaum millennial yang dekat dengan media sosial, proyek ini juga menciptakan ruang untuk memproduksi informasi digital tersebut dengan memberikan ruang mengulas otomotif atau studio review dan ruang kerja yang disebut workspace. Proyek ini berlokasi di Pantai Indah Kapuk dikarenakan saat ini daerah tersebut merupakan daerah masyarakat menengah ke atas, dekat dengan kaum millennial, dan sebagai titik temu para komunitas pecinta otomotif.
\end{abstract}

Kata kunci: Arsitektur; Kreativitas; Millennial; Modifikasi; Otomotif; Teknologi

\begin{abstract}
Millennials are a generation born from 1981 to 2000. This generation is very close to various kinds of technological developments. One of the fields of technology favored by the millennial generation is automotive technology. This is indicated by the increasing routine of automotive activities held from year to year such as seminars, exhibitions, modification, review, etc. The most preferred activity in automotive technology is modification activities. Modification activities are activities that can explore the creativity of millennial clams that are poured through automotive technology. Automotive modification activities are used as a new lifestyle and light science. Unfortunately, the Capital City has not been able to provide adequate space and facilities for the automotive modification activities. All these modification activities are still carried out conventionally and in open places. Whereas when viewed again, automotive modification activities with adequate facilities and space will increase the level of creativity of the millennials so that the results can compete with foreign countries. By tracing various observations in this millennial era, all forms of information about automotive are very easily packed with social media such as youtube, instagram, twitter, etc. For this reason, the author examines how architecture creates a container that functions optimally for automotive modification activities with an architectural project called the Car Modification Center at Pantai Indah Kapuk. The method used is the literature study method by examining the space typology of several projects that have been built. In response to millennial habits that are close to social media, the project also created space to
\end{abstract}


produce digital information by giving the room a review of automotive or studio reviews and workspaces called workspaces. This project is located at Pantai Indah Kapuk because currently the area is an area of middle to upper society, close to the millennials, and as a meeting point for the community of automotive lovers.

Keywords: Architecture; Automotive; Creativity; Millennial; Modification; Technology

\section{PENDAHULUAN}

Salah satu fenomena penting dari proses globalisasi adalah terlahirnya sebuah generasi yang disebut generasi millennial. Generasi millennial merupakan generasi yang lahir pada tahun 1981 hingga tahun 2000. Mereka kini berperan sebagai mahasiswa, early jobber dan orangtua muda. Generasi ini banyak menggunakan teknologi komunikasi instan seperti email, SMS, instant messaging dan media sosial seperti facebook dan twitter, dengan kata lain generasi millennial adalah generasi yang tumbuh pada era internet booming (Lyons, 2004) ${ }^{1}$.

Lebih lanjut Lyons mengungkapkan ciri-ciri dari generasi millennial adalah: karakteristik masing-masing individu berbeda, tergantung dimana ia dibesarkan, strata ekonomi, dan sosial keluarganya. Pola komunikasinya sangat terbuka dibandingkan generasi-generasi sebelumnya, pemakai media sosial yang fanatik dan kehidupannya sangat terpengaruh dengan perkembangan teknologi. Lebih terbuka dengan pandangan politik dan ekonomi, sehingga mereka terlihat sangat reaktif terhadap perubahan lingkungan yang terjadi di sekelilingnya.

Perkembangan teknologi yang semakin canggih sangat mempengaruhi gaya hidup manusia saat ini. Teknologi berkembang pesat di berbagai bidang dan selalu muncul penemuan baru setiap harinya baik dalam bidang IT, Pendidikan, Perdagangan, Militer dan Transportasi yang pada prinsipnya teknologi ini berkembang untuk memenuhi kebutuhan dan keinginan manusia agar dalam kehidupan dapat lebih mempermudah melakukan aktivitas atau kegiatan apapun. Salah satunya yakni perkembangan teknologi transportasi atau otomotif. Di Indonesia, otomotif sudah berkembang sangat pesat dimana dunia otomotif turut memiliki andil dalam pertumbuhan ekonomi negara. Hal ini terbukti dengan adanya antusiasme masyarakat yang besar dalam merespon perkembangan otomotif, sehingga sektor industri otomotif kini memegang predikat sebagai salah satu diantara 24 perusahaan penyumbang pajak terbesar di Indonesia ${ }^{2}$.

Selain penyumbang pajak terbesar, kegiatan dalam dunia otomotif di Indonesia cukup beragam, seperti balap mobil, pameran otomotif yang biasanya memperkenalkan produkproduk baru serta ajang kompetisi modifikasi mobil. Dari sekian kegiatan-kegiatan otomotif tadi, salah satu yang paling diminati penggemar otomotif tanah air adalah kegiatan memodifikasi kendaraan, karena dibidang yang satu ini setiap orang dengan bebas dapat mengekspresikan ide kreatifitasnya. Kendaraan yang dimiliki para penggemar otomotif tidak hanya sebatas alat transportasi, tetapi dikalangan ini kendaraan sudah menjadi gaya hidup yang menunjukkan identitas dan jati diri mereka, walaupun harus mengorbankan biaya, waktu dan tenaga yang besar.

Kegiatan modifikasi otomotif yang dilakukan oleh para modifikator merupakan sebuah bentuk kreativitas yang berawal dari sebuah ide atau imajinasi. Kaum modifikator yang termasuk dalam generasi millennial ini merupakan kaum yang dikenal sebagai kaum yang penuh akan imajinasi dan angan-angan ekstrim. Dari ide-ide tersebut terciptalah sebuah inovasi baru yang dapat berguna untuk banyak orang, sehingga hal ini tidak dapat disepelekan begitu saja.

\footnotetext{
${ }^{1}$ Lyons, S. (2004). An exploration of generational values in life and at work., 441-441. Dikutip dari http://ezproxy.um.edu.my/docview/305203456?accountid=28930

${ }^{2}$ Kuswarahardja, Dadan. APM Otomotif Salah Satu Penyumbang Pajak Terbesar Tahun 2015, dikutip dari https://oto.detik.com/mobil/d-3187228/apm-otomotif-salah-satu-penyumbang-pajak-terbesar-tahun2015
} 
Oleh sebab itu aktivitas ini membutuhkan sebuah wadah yang layak untuk kaum mudah dapat mengembangkan daya kreatif inovatifnya secara bebas dan berfokus. Pada tempat ini, para kaum millennial pecinta modifikasi mobil memiliki kesempatan sebebas-bebasnya beraktivitas dengan menyalurkan bakat dan minat serta mengasah kematangan kreativitasnya.

\section{KAJIAN LITERATUR}

\section{Generasi Millennial}

Saat ini terdapat empat cohort besar dalam sebuah demograsi yakni Baby Boomer (lahir pada tahun 1946-1964), Gen-X (lahir pada tahun 1965-1980), Millennial (lahir pada tahun 1981-2000), dan Gen-Z (lahir pada tahun 2001-sekarang). Dalam literatur lain yakni menurut Absher dan Amidjaya yakni menyebutkan bahwa generasi Millennial merupakan sebuah generasi yang lahir berkisar antara 1982-2002, hal ini terlihat terjadi perbedaan selisih yang tidak terlalu signifikan (Ali \& Lilik Purwandi, 2017).

Generasi dalam era millennial merupakan google generation, net generation, echo boomers, dan dumbest generation. Oleh karena itu, munculnya generasi millennial dapat terlihat dari meningkatnya penggunaan alat telekomunikasi, media dan teknologi informasi yang digunakan seperti internet, youtube, facebook, instagram dan media-media lainnya. Hal ini dapat dijadikan sebagai inovasi karena generasi millennial mencari, belajar dan bekerja di dalam lingkungan yang memiliki inovasi yang sangat mengandalkan teknologi untuk melakukan perubahan di dalam berbagai aspek kehidupan. (Endang Fatmawati, 2010) ${ }^{4}$.

Kreatif merupakan suatu kondisi dimana seseorang dapat memberikan gagasan-gagasan atau sesuatu yang baru, sesuatu yang mungkin berbeda dengan apa yang sudah ada biasanya dan hal tersebut mungkin untuk diwujudkan atau inovasi. Kreativitas merupakan unsur yang cukup penting keberadaannya dan berkembangnya pribadi yang lebih baik. Kaum muda yang ingin maju dan berkembang menjadi pribadi yang lebih baik dan harus dapat menciptakan kondisi yang memungkinkan setiap unsur bisa kreatif. Hal tersebut menjadi syarat kondusif bagi munculnya ide-ide kreatif. Apabila suatu pemikiran diberi ruang lega makan akan lahir banyak ide baru. Ide kreatif itu sendiri akan terjadi karena suatu proses. Kreativitas tidak diperolah begitu saja tetapi melalu proses pengalaman, latihan dan mencoba.

Salah satu sarana mengekspresikan diri bagi generasi millennial yang cukup diminati yakni modifikasi otomotif. Untuk dapat menghasilkan suatu karya modifikasi yang baik, menarik tentunya dibutuhkan sebuah kreatifitas. Jiwa yang kreatif-inovatif mampu memunculkan suatu karya modifikasi yang berbeda dari yang lain dan memiliki ciri dan karakter tersendiri. Seperti yang dapat kita lihat dari hasil survey berikut ini, 62,1 \% dari 95 responden yang tergolong sebagai kaum millennial, menjawab suka memodifikasi mobil.

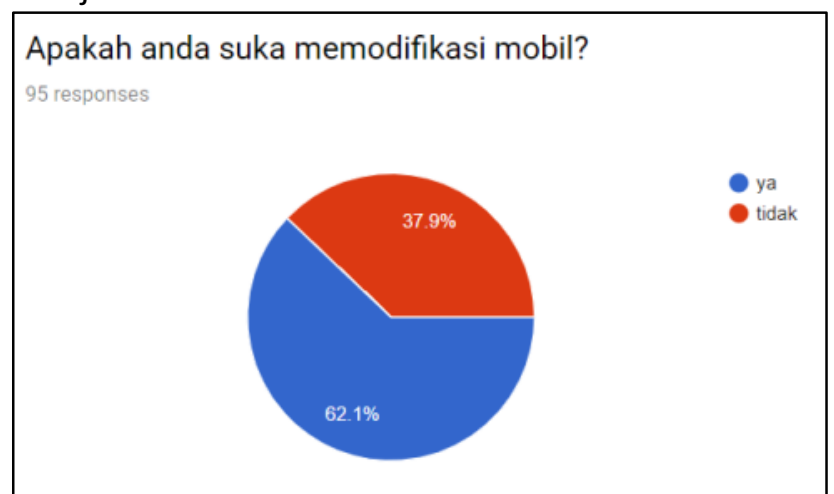

Gambar 1. Diagram Responden yang Suka Modifikasi Mobil

Sumber: Penulis, 2019

\footnotetext{
${ }^{3}$ Ali, H., \& Lilik Purwandi. (2017). Millennial Nusantara Pahami Karakternya, Rebut Simpatinya. Jakarta: PT Gramedia Pustaka Utama.

${ }^{4}$ Endang Fatmawati, “. P. (2010, Agustus). Fatmawati, Endang . Visi Pustaka, 12(2).
} 
Generasi millennial yang kreatif merupakan kaum muda yang berani mengambil resiko. Hanya saja seberapa besar kualitas kreatifitas yang dimiliki setiap pribadi tersebut mampu diwadahi, dikembangkan dan ditekuni agar menjadi positif. Aspek paling mendasar dari kreatifitas merupakan pribadi. Ciri kreatif pada pribadi antara lain kemampuan untuk berfikir, kelancaran mempergunakan ide, kelenturan dalam memandang masalah, orisinalitas dan elaborasi yakni kemampuan merinci dan memperkaya gagasan.

Ciri generasi millennial yang kreatif dan inovatif antara lain;

a. Mampu berfikir secara konvergen dan divergen

b. Conceptual Flexibility merupakan mampu secara spontan mengganti cara memandang atau pendekatan terhadap sesuatu

c. Orisionalitas merupakan memiliki sifat asli, kemampuan berfikir dan dapat merespon hal unik yang berada dalam diri kita masing-masing.

d. Lebih menyukai complexitas dari pada simplisitas yakni hal-hal yang rumit dan menantang dipandang dapat memperkaya wawasan dan juga cara pandang.

e. Memiliki kecakapan dalam banyak hal atau disebut juga dengan multiple skill yakni memilki kemampuan terhadap banyak hal dalam hidup, tidak hanya berfokus pada suatu pekerjaan saja. ${ }^{5}$

Menurut SEMA Young Accessorizers Report 2018, kaum millennial banyak menghabiskan sebagian besar uangnya untuk kepentingan modifikasi kendaraannya, seperti yang ditunjukkan pada grafik dibawah ini;

\section{LAST YEAR, YOUNG PEOPLE SPENT \$7.2B MODIFYING THEIR CARS}

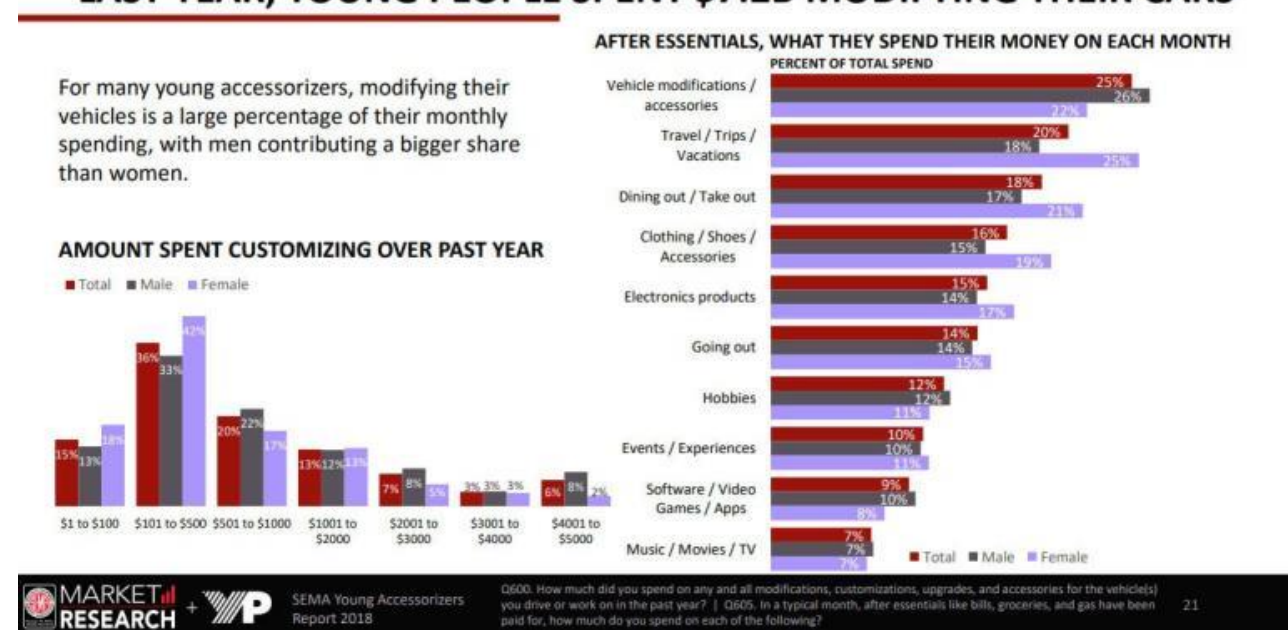

Gambar 2.. Grafik Persentase Pengeluaran Kaum Millennial Per Bulannya Sumber: www.autonetmagz.com

\section{Otomotif}

Otomotif merupakan salah satu cabang ilmu teknik mesin yang mempelajari mengenai bagaimana merancang, membuat dan mengembangkan alat-alat transportasi darat yang menggunakan mesin. Mesin yang dipelajari merupakan mesin sepeda motor, mobil, bis dan truk.

\footnotetext{
${ }^{5}$ Tinjauan Modifikasi Otomotif Mobil Sedan. (Sport Car) http://ejournal.uajy.ac.id/3313/3/2TA12420.pdf
} 


\section{Modifikasi Otomotif}

Pengertian Modifikasi

Kata modifikasi berasal dari bahasa Inggris yakni modification. Berikut ini beberapa pengertian

a. Modify : 1 memodifikasi, mengubah, 2 membatasi, 3 mengurangi (John M. Echols, Kamus Inggris-Indonesia hal. 384)

b. Modification : modifikasi, perubahan (John M. Echols, Kamus Inggris-Indonesia, hal. $384)^{6}$

c. Modifikasi : 1 perubahan, 2 pergantian atau penambahan sesuati $(\mathrm{KBBI} \text {, hal } 653)^{7}$

Dari ketiga hal tersebut dapat ditarik kesimpulan mengenai modifikasi yakni merubah dari kondisi semula. Maka dari itu modifikasi otomotif merupakan perubahan yang dilakukan pada kendaraan, baik kendaraan mobil maupun motor, besar maupun kecil yang membuat kondisi kendaraan tersebut berbeda dari sebelumnya.

\section{Sejarah Modifikasi Otomotif}

Kegiatan modifikasi ini dilakukan seiring berkembang zaman serta perkembangan ilmu pengetahuan dan teknologi. Terlihat dari berkembangnya teknologi pada kendaraan sepeda motor maupun mobil telah jauh berbeda dengan teknologi puluhan tahun lalu. Setiap tahun dikeluarkan inovasi dan teknologi baru yang lebih canggih sebagai ubahan modifikasi yang lama. Ubahan pada mesin-mesin teknologi mesin injeksi saat ini mampu membuat kendaraan melaju atau memiliki peforma yang cukup kencang, akan tetapi walaupun memiliki peforma yang cukup kencang tidak perlu memakai bahan bakar yang cukup banyak atau tetap irit bahan bakar.

Seiring perkembangan zaman, banyak orang yang merasa tidak puas terhadap mobil yang diproduksi oleh pabrik, terkadang muncul rasa ingin menciptakan kendaraan yang sesuai dengan keinginan dan imajinasi mereka baik dari segi fungsional maupun estetika. Fenomena ini berawal pada tahun 1960-an, perkembangan teknologi mulai berkembang seperti televise, media massa maupun game turut mempengaruhi berkembangnya minat modifikasi automotif. Hal ini dimulai dari Negara di Eropa dimana Negara tersebut merupakan pusat pabrikan otomotif sehingga di Negara tersebut hal mengenai otomotif merupakan hal yang tidak asing lagi. Membuat perbedaan, memiliki ciri khas, meningkatkan gengsi dan pristise, mendapat pengakuan dan mewujudkan impian itulah hal yang ingin dicapai dari modifikasi otomotif.

\section{Jenis Modifikasi Otomotif}

Modifikasi mobil secara garis besar terbagi menjadi 3 yaitu:

a. Modifikasi Interior

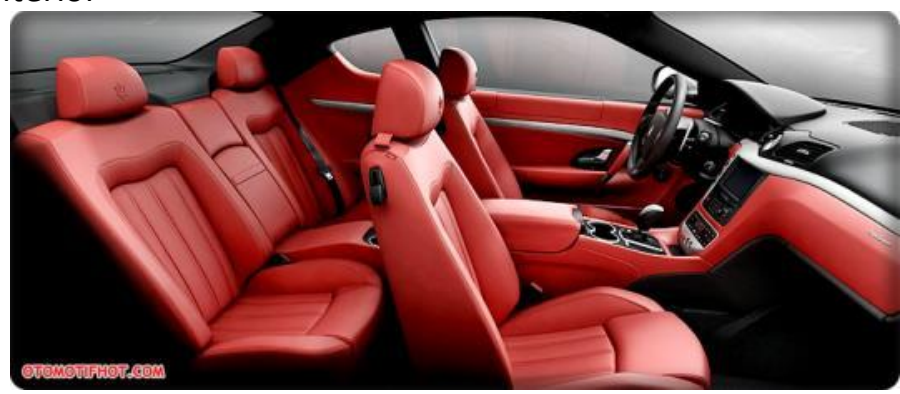

Gambar 3. Contoh Modifikasi Interior

Sumber : www.otomotifhot.com

Modifikasi Interior merupakan modifikasi yang dilakukan pada bagian dalam mobil atau bagian interior. Jenis modifikasi interior mobil yakni modifikasi dashboard, seat, door trim, audio, dan lain-lain.

\footnotetext{
${ }^{6}$ John M. Echols, Kamus Inggris-Indonesia

${ }^{7}$ Kamus Besar Bahasa Indonesia, hal 653
} 
b. Modifikasi Eksterior

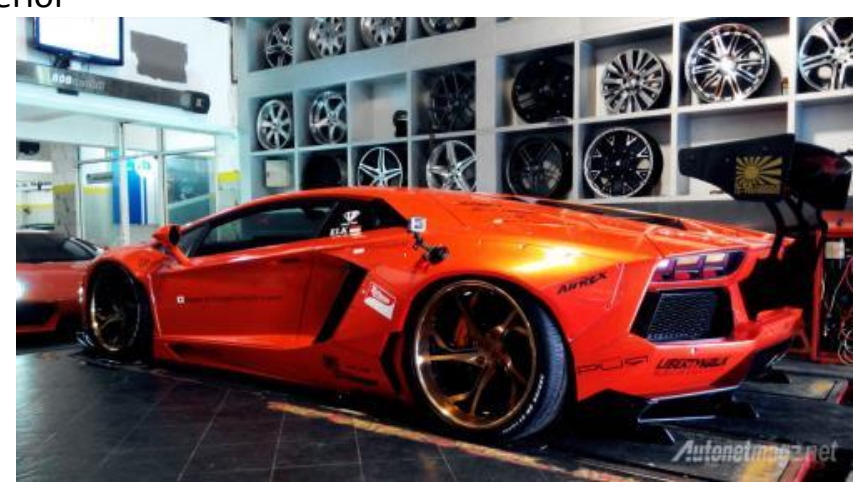

Gambar 4. Contoh Modifikasi Eksterior

Sumber : www.autonetmagz.com

Modifikasi Eksterior merupakan modifikasi yang dilakukan pada bagian luar mobil. Jenis modifikasi ini paling banyak dilakukan karena memiliki banyak varian atau variasi, dan dapat langsung diperlihatkan hasil desainnya. Macam-macam modifikasi eksterior yakni Front \& Rear Bumper, Side Skirt, Spoiler, Sun Roof, Hood, Light, Paint, Graphic, Wheel, Suspension, dan lain-lain.

c. Modifikasi Mesin

Modifikasi yang dilakukan pada bagian mesin yang berfungsi untuk merubah tampilan dan meningkatkan peforma. Jenis modifikasi mesin mobil yakni, Engine, Ecu, Transmission, Turbo, dan lain-lain.

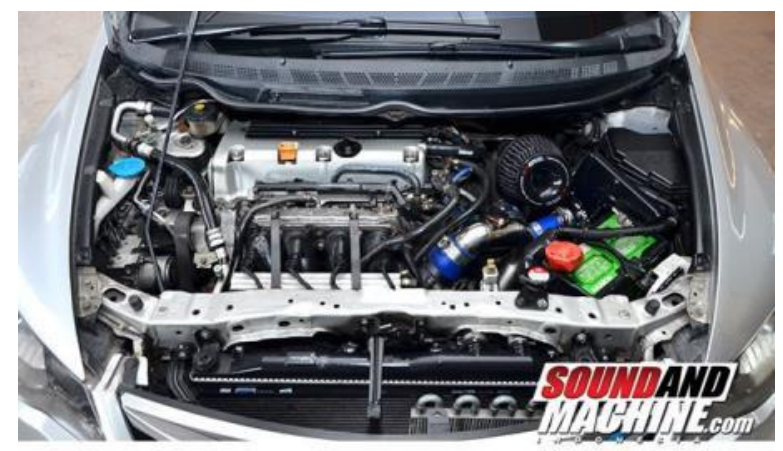

Gambar 5. Contoh Modifikasi Mesin

Sumber : www.soundandmachine.com

Menurut SEMA Young Accessorizers Report 2018, berikut grafik yang menunjukan persentase bagian-bagian mobil untuk di modifikasi.

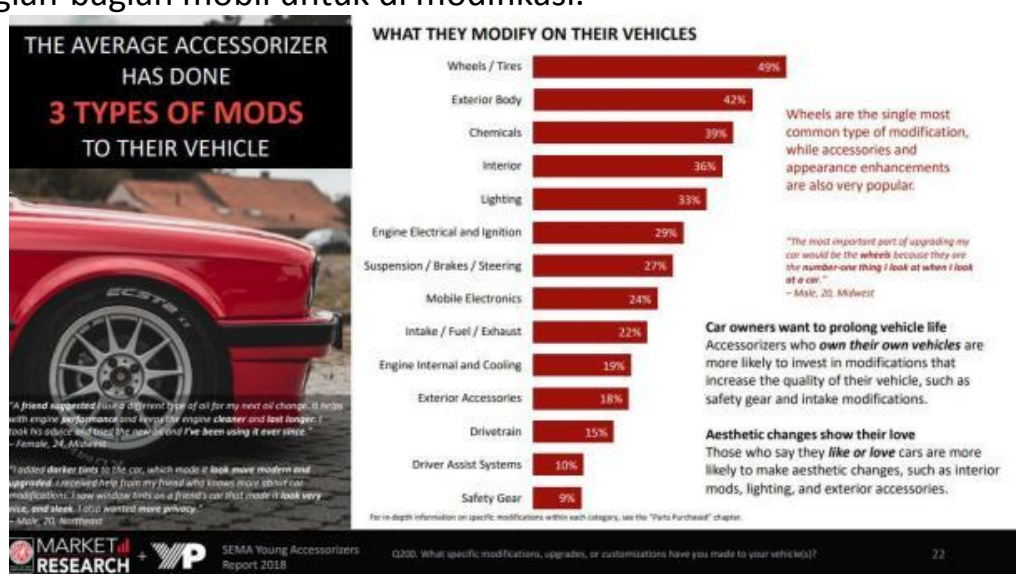

Gambar 6. Persentase Bagian-Bagian Mobil yang Dimodifikasi Sumber : Autonetmagz 


\section{Persyaratan Fasilitas Modifikasi Otomotif}

Dalam kegiatan modifikasi memerlukan beberapa fasilitas yang memerlukan beberapa persyaratan yakni:

a. Persyaratan Bengkel

Tian Burger merupakan pakar perencana bengkel, merencanakan persyaratan dalam merancang bengkel yakni;

- Safety.

- Cleanliness.

- Storage.

- Work movement.

- Ergonomic.

b. Bengkel merupakan tempat peralatan perawatan atau perbaikan kendaraan modifikasi. Kegiatan umum yang terjadi di bengkel modifikasi antara lain;

- Engine (mesin) : Seperti tune up; kontroling terhadap minyak, pelumas dan baut, balancing, spooring.

- Perbaikan : dibagi menjadi perbaikan ringan yakni perbaikan yang tidak perlu membongkar mesin seperti busi, kabel dan perbaikan berat yang mengharuskan pembongkaran mesin.

- Body Chasis repair

- Ketok Magic yakni melakukan perbaikan bodi yang rusak

- Custom dan Body Kid

- Penjualan Sparepart

- Penjualan aksesoris atau variasi modifikasi otomotif

- Salon dan Cuci mobil ${ }^{8}$

\section{Modifikasi Otomotif sebagai Sarana Berekspresi dan Pengembangan Kaum Muda}

Masa muda merupakan masa peralihan yang penting dalam perkembangan pemikiran, penemuan bakat dan kreatifitas. Beberapa kognitif (Adilescense, 2003, Hal.21) yang memungkinkan peningkatan pemikiran kritis pada remaja antara lain:

a. Meningkatnya kecepatan, otomatisasi dan kapasitas pemprosesan informasi yang membebaskan sumber kognitif untuk dimanfaatkan bagi tujuan lain

b. Bertambah luasnya isi pengetahuan mengenai berbagai bidang

c. Meningkatnya kemampuan membangun kombinasi-kombinasi baru dari pengetahuan

d. Semakin panjangnya rentang dan spontannya penggunaan strategi atau prosedur untuk menerapkan atau memperoleh pengetahuan, seperti perencanaan, mempertimbangkan berbagai pilihan dan pemantauan kognitif.

Modifikasi otomotif merupakan salah satu sarana generasi millennial dalam berekspresi. Melalui modifikasi tersebut generasi millennial berusaha untuk menjadi mengembangkan minat dan bakat secara kreatif-inovatif dalam berkarya. Kepuasan diri, menginginkan sesuatu yang khas dan berbeda dengan yang lainnya, meningkatkan gengsi dan rasa percaya diri itu juga hal yang dicari oleh mereka yang melakukan modifikasi.

\footnotetext{
8 Persyaratan Fasilitas Modifikasi Otomotif. Sumber:

https://www.bukucatatan.net/2018/08/persyaratan-fasilitas-modifikasi-otomotif.html
} 


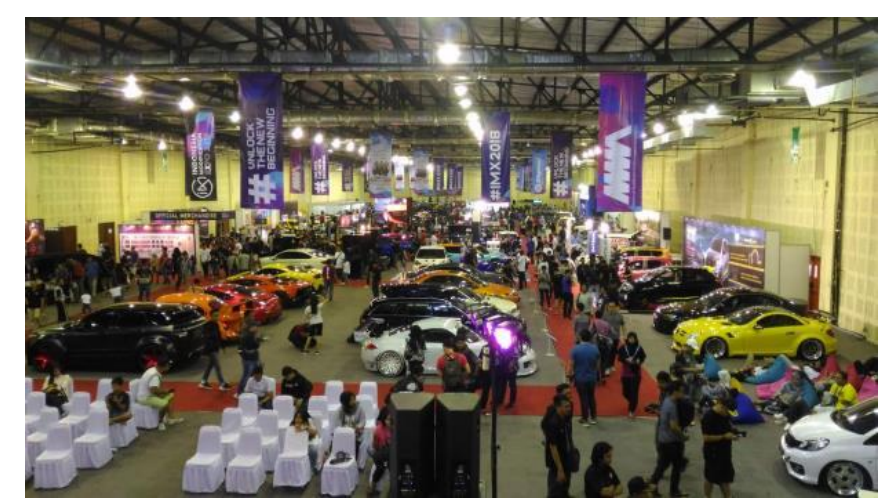

Gambar 7. Indonesia Modification Expo 2018

Sumber : http://nmaa.co.id

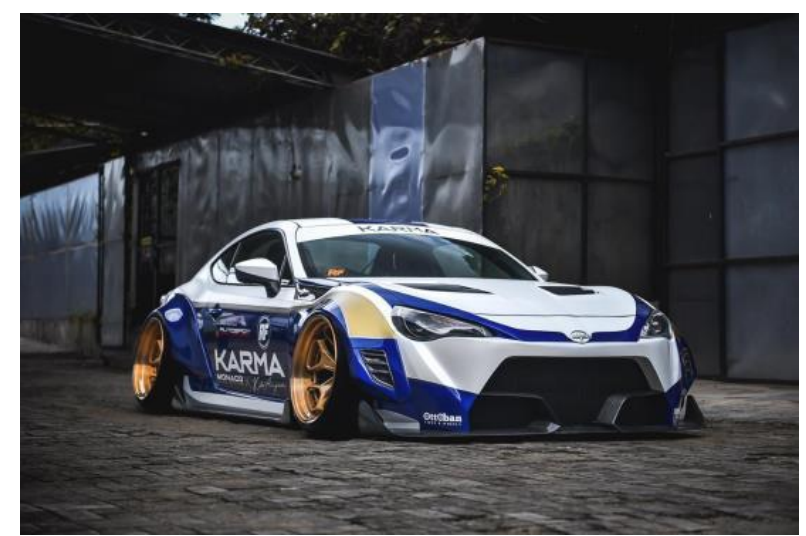

Gambar 8. Produk Body Kit Lokal

Sumber : http://nmaa.co.id

\section{METODE PERANCANGAN}

Menurut Buku Metode Perancangan (Gunawan Tjahjono : hal 55), Metode Tipologi Ruang Kegiatan dilakukan dengan cara memahami kegiatan manusia yang paling mendasar. Dengan mempelajari kegiatan manusia secara baik, kegiatan tersebut menciptakan sebuah ruang. Dalam konteks kegiatan modifikasi mobil, perancang perlu mencari kegiatan apa saja yang terjadi sehingga dari kegiatan tersebut dapat mengetahui kebutuhan ruang. Selain itu perancang perlu memahami ergonomic yang dibutuhkan dalam menentukan ruang tersebut.

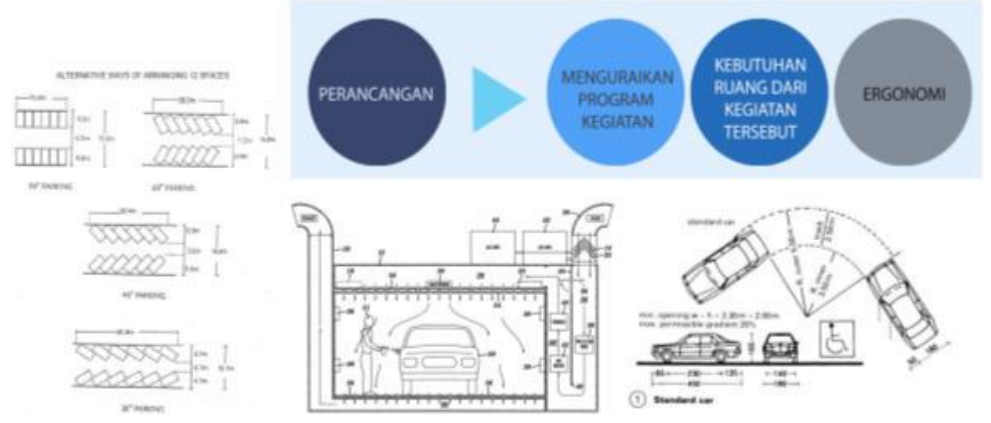

Gambar 9. Produk Body Kit Lokal

Sumber : Buku Gunawan Tjahjono hal 55

Selain mengutip panduan metodelogi dari sumber di atas, beberapa tahapan perancangan yang dilakukan adalah sebagai berikut;

a. Metode Pengumpulan data, dilakukan dengan cara

- Dengan melakukan survey lapangan dan observasi data 
- Dengan mencari literatur dari berbagai sumber sebagai studi pustaka

- Dengan melakukan studi kasus pada proyek serupa dengan memperdalam tipologi dan kebutuhan ruang.

b. Metode Analisa

- Melakukan analisa makro

- Melakukan analisa mikro

- Melakukan analisa tapak

- Melakukan analisa hubungan antar ruang

c. Metode sintesis

- Menghubungkan hasil analisa terhadap fungsi bangunan dan menjawab segala analisa dengan solusi

d. Metode perumusan konsep, pembentukan gubahan massa dan penysusunan ruang.

4. DISKUSI DAN HASIL

Diskusi

a. Pengenalan dan Analisa Lokasi Proyek

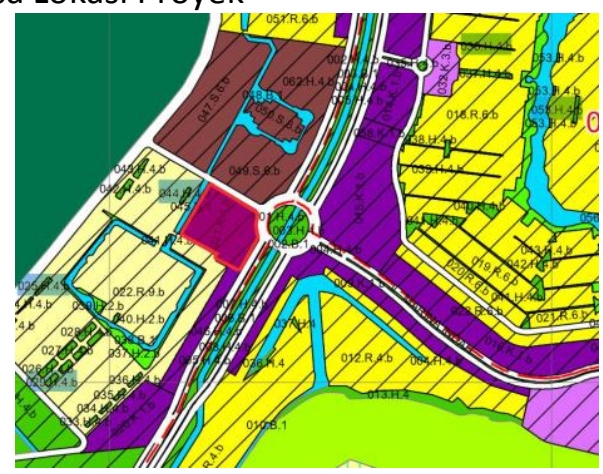

Gambar 10. Lokasi Tapak Proyek

Sumber: Penulis, 2019

Pusat Modifikasi Mobil berlokasi di Jalan Pantai Indah Kapuk, RT.6/RW2, Kamal Muara, Penjaringan, Kota Jakarta Utara, Daerah Khusus Ibukota Jakarta 14470. Lokasi Pantai Indah Kapuk dipilih sebagai lokasi yang paling sesuai dengan fungsi bangunan yaitu modifikasi mobil untuk kaum millennial. Lokasi tapak berada dekat dengan permikan permukiman masyarakat menengah ke atas dan juga dekat dengan tempat berkumpul kaum millennial yang populer sekarang ini. Selain itu, Pantai Indah Kapuk memiliki fasilitas jalan yang lebar dan baik dan karena itu juga kawasan Pantai Indah Kapuk seringkali dijadikan sebagai titik temu para komunitas Mobil.

b. Gubahan massa

Proses gubahan massa dimulai dari memotong area tapak dengan garis batas bangunan, sehingga ditemukan bentuk lahan yang dapat terbangun. Tahap kedua, memberikan ruang luar yang dalam perancangan ini, ruang tersebut dijadikan sebagai tempat parkir. Kemudian gubahan massa tersebut dibagi ke dalam 3 buah massa bangunan dan membentuk massa sesuai dengan fungsinya. Proses gubahan massa tersebut dijelaskan dalam gambar dibawah ini; 
TRANSFORMASI GUBAHAN MASSA

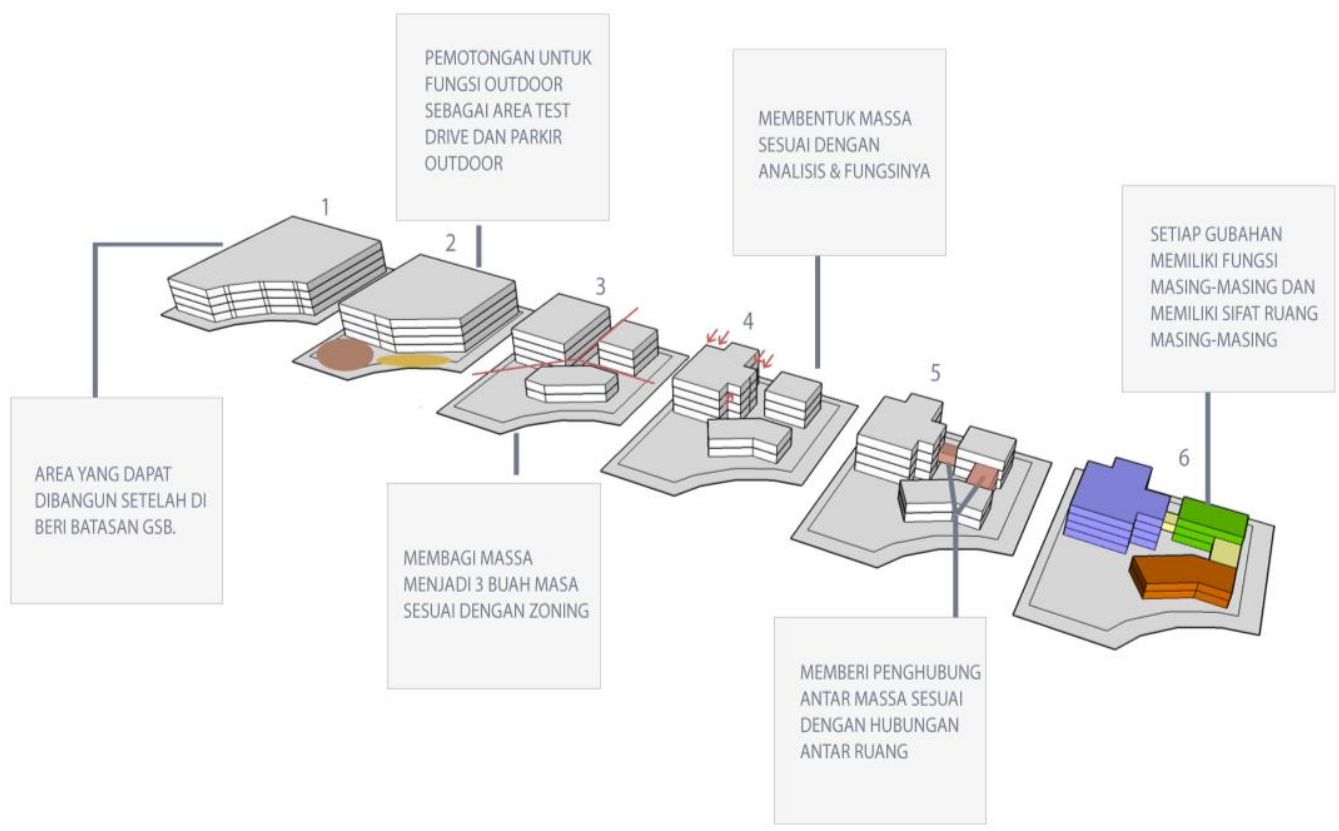

Gambar 11. Proses Gubahan Massa

Sumber: Penulis, 2019

\section{Hasil Desain}

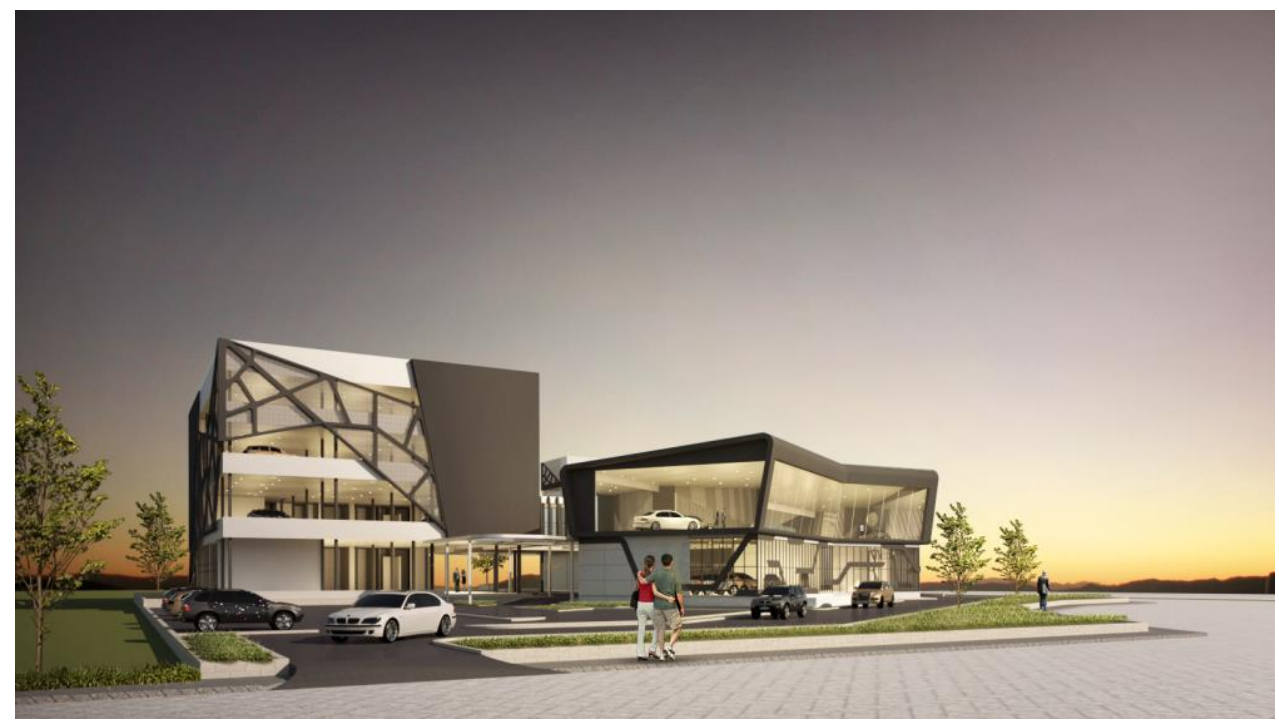

Gambar 12. Exterior Bangunan

Sumber: Penulis, 2019 
Denah Bangunan

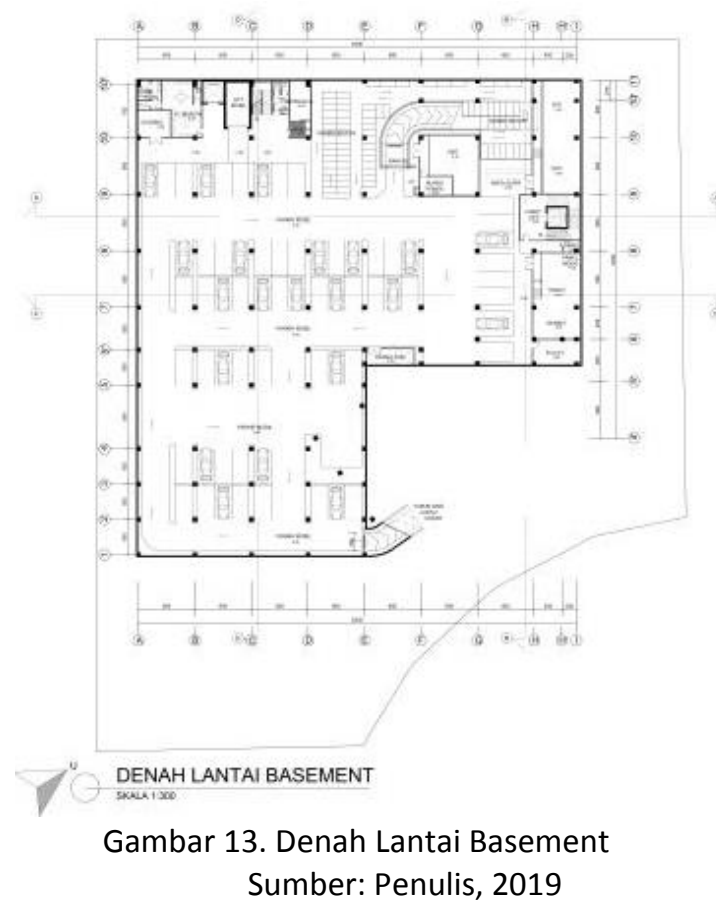

Denah lantai basement menggambarkan bahwa pada lantai ini sebagian besar merupakan tempat parkir mobil. Pada lantai basement dilengkapi juga dengan parkir motor, ruang genset, ruang STP, WTP, GWT, musholla, ruang montir, dan gudang.

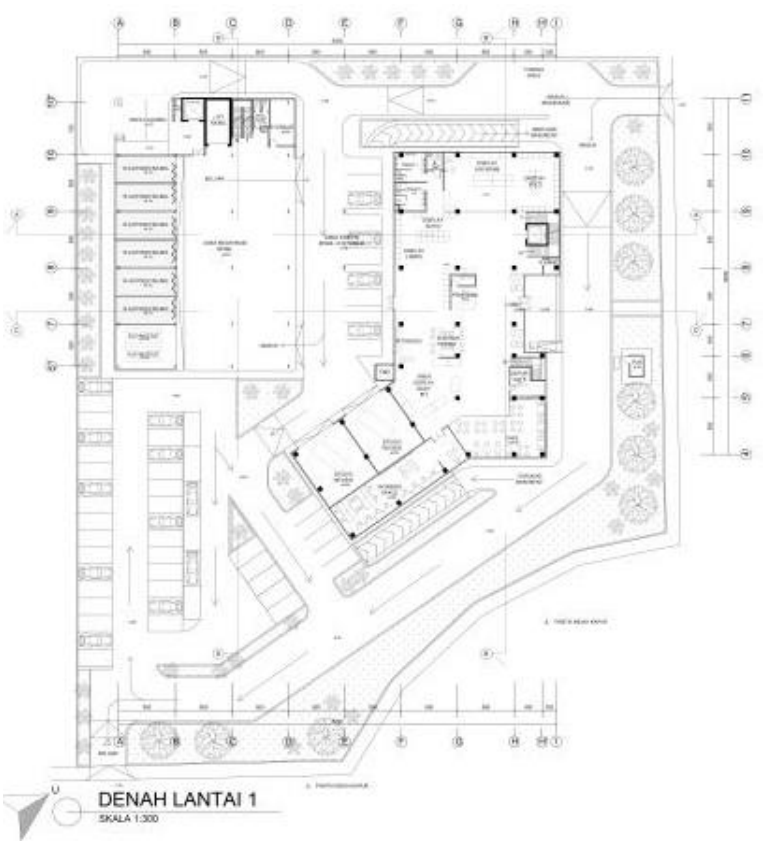

Gambar 14. Denah Lantai Dasar

Sumber: Penulis, 2019

Denah lantai dasar berisi ruang studio review, café, workspace, ruang penerima, pameran sparepart mobil, toilet, dan ruang modifikasi mobil khususnya bagian dyno test dan autodetailing. 


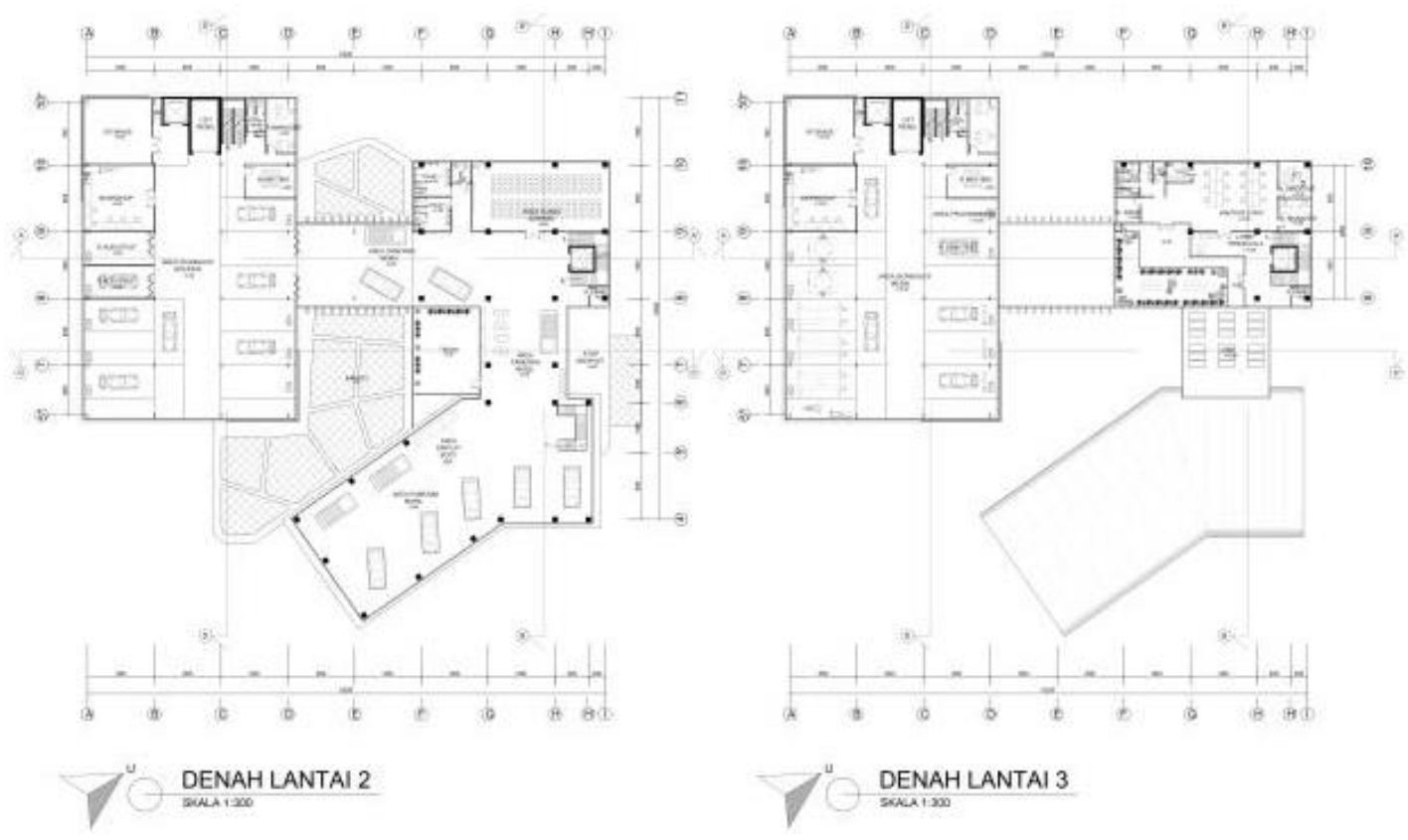

Gambar 15. Denah Lantai 2 dan 3

Sumber: Penulis, 2019

Denah lantai dua terdapat area modifikasi interior mobil, ruang pameran mobil hasil modifikasi, ruang seminar, dan toilet. Pada lantai 3 terdapat area modisikasi mesin, dan kantor pengelola.

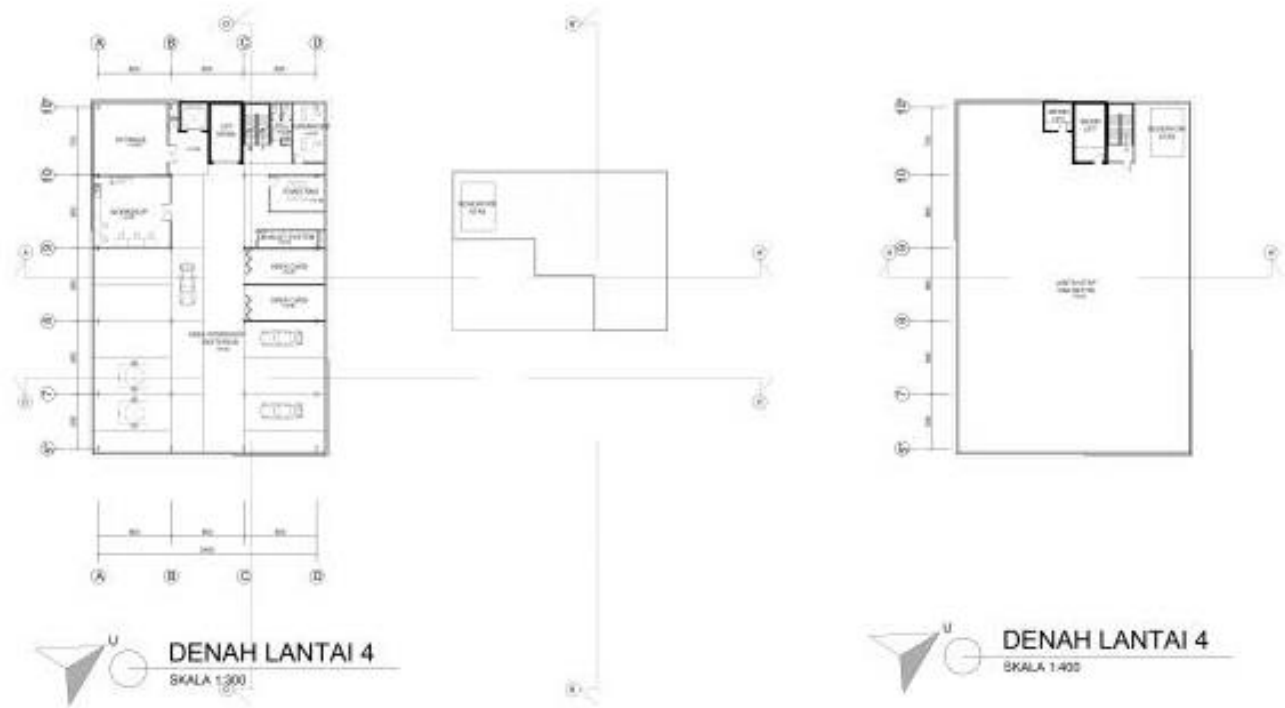

Gambar 13. Denah Lantai 4 dan Atap.

Sumber: Penulis, 2019

Denah lantai 4 terdapat area modifikasi eksterior mobil. Dan pada lantai atap merupakan tempat untuk meletakan reservoir atas dan mesin lift. Dari seluruh denah dapat dilihat bahwa sistem sirkulasi vertical bangunan ini menggunakan sebuah lift dan tangga. 


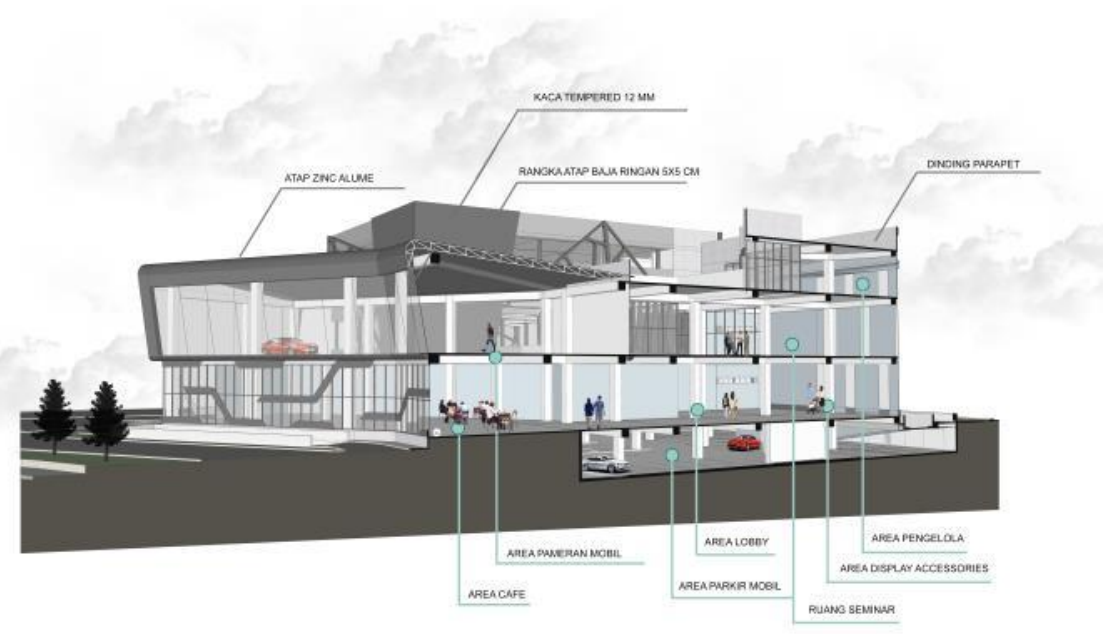

Gambar 14. Potongan Perspektif bangunan

Sumber: Penulis, 2019

\section{KESIMPULAN DAN SARAN}

Pusat Modifikasi Mobil atau Car Auto-Modif di Pantai Indah Kapuk merupakan sebuah tempat atau wadah untuk generasi millennial yang memiliki ketertarikan dengan dunia otomotif atau kegiatan modifikasi otomotif. Seperti yang menjadi dasar pemikiran untuk perancangan ini, kurangnya fasilitas yang memadahi di ibu kota dalam mewadahi aktivitas modifikasi mobil kaum millennial. Berlandaskan karakteristik generasi millennial yang cenderung memiliki tingkat kreativitas yang tinggi, serta sangat mengikatkan diri pada kemajuan teknologi informasi, yakni media sosial, maka bangunan ini didesain lengkap dengan fasilitas ramah generasi millennial. Ruang-ruang yang ditujukan pada karakteristik generasi millennial tersebut adalah ruang studio review mobil, ruang pameran, ruang seminar, dan workspace. Proyek ini dinamakan Pusat Modifikasi Mobil di Pantai Indah Kapuk, merupakan proyek yang diharapkan dapat menjadi wadah pengembangan kreativitas kaum millennial dan bertujuan untuk mendorong generasi millennial kreatif akan otomotif untuk dapat bersaing dengan negara luar sehingga dapat memajukan nama bangsa dan negara.

\section{REFERENSI}

Ali, H., \& Purwandi, L. (2017). Millennial Nusantara Pahami Karakternya, Rebut Simpatinya. Jakarta: PT Gramedia Pustaka Utama.

Commission of the European Communities. (2001). Governance in the European Union: a

White Paper. Retrieved August 21, 2001, from

http://europa.eu.int/governance/white_paper/index_en.htm

Haynes, J. (2005). Comparative politics in a globalizing world. Cambridge: Polity.

John M. Echols, Kamus Inggris-Indonesia

Kamus Besar Bahasa Indonesia, hal 653

Kamus Besar Bahasa Indonesia Online, https://kbbi.web.id/

Lyons, S. (2004). An exploration of generational values in life and at work., 441-441. Dikutip : http://ezproxy.um.edu.my/docview/305203456?accountid=28930

NMAA Team. Indonesia Modification Expo 2018 Resmi Dibuka Hari Ini! Sumber : http://nmaa.co.id/2018/11/indonesia-modification-expo-2018-resmi-dibuka-hari-ini/

Persyaratan Fasilitas Modifikasi Otomotif. Sumber: https://www.bukucatatan.net/2018/08/persyaratan-fasilitas-modifikasi-otomotif.html

Tinjauan Modifikasi Otomotif Mobil Sedan. (Sport Car) http://e-journal.uajy.ac.id/3313/3/2TA12420.pdf

Tjahjono, G. Metode Perancangan Suatu Pengantar untuk Arsitek dan Perancang, Hal : 55 
